University of Nebraska - Lincoln

DigitalCommons@University of Nebraska - Lincoln

Faculty Publications: Department of

Entomology

Entomology, Department of

2007

\title{
Abundance and diversity of ground-dwelling arthropods of pest management importance in commercial Bt and non-Bt cotton fields
}

J. B. Torres

Universidade Federal Rural de Pernarnbuco, jtorres@ufrpe.br

J. R. Ruberson

University of Georgia

Follow this and additional works at: https://digitalcommons.unl.edu/entomologyfacpub

Part of the Entomology Commons

Torres, J. B. and Ruberson, J. R., "Abundance and diversity of ground-dwelling arthropods of pest management importance in commercial Bt and non-Bt cotton fields" (2007). Faculty Publications: Department of Entomology. 762.

https://digitalcommons.unl.edu/entomologyfacpub/762

This Article is brought to you for free and open access by the Entomology, Department of at DigitalCommons@University of Nebraska - Lincoln. It has been accepted for inclusion in Faculty Publications: Department of Entomology by an authorized administrator of DigitalCommons@University of Nebraska - Lincoln. 


\title{
Abundance and diversity of ground-dwelling arthropods of pest management importance in commercial Bt and non-Bt cotton fields
}

\author{
J.B. Torres ${ }^{1,2}$ \& J.R. Ruberson ${ }^{2}$ \\ 1 Departmento de Agronomia - Entomologia, Universidade Federal Rural de Pernambuco, Dois Irmãos, Recife, Pernambuco, Brazil \\ 2 Department of Entomology, University of Georgia, Tifton, GA, USA
}

\begin{abstract}
Keywords
Carabidae; Cicindelinae; Falconia gracilis; genetically modified cotton; Labiduridae; predatory heteropterans; Staphylinidae.

\author{
Correspondence \\ J.B. Torres, Departmento de Agronomia - \\ Pernambuco, Avenida Dom Manoel de \\ Medeiros, S/N, Dois Irmãos, 52171-900 \\ Recife, Pernambuco, Brazil. \\ Email: jtorres@ufrpe.br
} Entomologia, Universidade Federal Rural de
\end{abstract}

Received: 15 February 2006; revised version accepted: 24 July 2006.

doi:10.1111/j.1744-7348.2006.00087.x

\begin{abstract}
The modified population dynamics of pests targeted by the CrylAc toxin in Bacillus thuringiensis (Bt) transgenic cotton (Bt cotton) and possible reduced insecticide use in these transgenic varieties may exert a variety of effects on ground-dwelling predator communities. A survey of ground-dwelling arthropods was carried out weekly each of 3 years (during the cropping season) in commercial Bt and non-Bt cotton fields. Sixty-five taxa of ground-dwelling arthropods (carabids, cicindelines, staphylinids, dermapterans, heteropterans and araneids) of importance for cotton pest management were recorded in the survey. Species abundance and dynamics across seasons were evaluated with univariate analysis of variance for higher taxa or multivariate principal response curve analysis for the whole community of 65 taxa. Diversity and richness indices and cumulative species curves also were calculated. The analyses demonstrated no differences in the ground-dwelling arthropod communities between cotton types. One araneid species, Pardosa pauxilla, comprised $\sim 80 \%$ of all araneids, Labidura riparia comprised $\sim 96 \%$ of all dermapterans, Megacephala carolina comprised $\sim 97 \%$ of cicindelines and four carabid species (Selenophorus palliatus, Apristus latens, Harpalus gravis and Anisodactylus merula) comprised $\sim 80 \%$ of carabid species. M. carolina outnumbered all other collected species in each of the 3 years. When only predatory carabid species were considered, A. merula, Calosoma sayi, Harpalus pennsylvanicus and Stenolophus ochropezus were predominant and numbers trapped were similar between cotton types. The abundance of dermapterans, staphylinids, araneids and heteropterans varied among sample dates and across seasons but did not differ between cotton types. The frequent capture of M. carolina, S. palliatus and P. pauxilla in all fields and seasons in both cottons suggests that these species may be important for monitoring further changes in local communities as result of agricultural practices.
\end{abstract}

\section{Introduction}

There is considerable interest in determining risks and benefits of agricultural practices for conservation of arthropod communities important for pest control and sustainability. In this context, ground-dwelling arthropod communities, composed of a variety of species with differ- ent feeding behaviours, have been used to assess the impact of pest management practices and cropping systems on beneficial arthropods (Eyre et al., 1989; Carmona \& Landis, 1999). Omnivorous and generalist arthropods are commonly found among ground-dwelling communities, and their role in suppressing pests may be quite significant (Stinner \& House, 1990; Breene et al., 
1993; Lövei \& Sunderland, 1996; Knisley \& Schultz, 1997). The conservation of certain groups of grounddwelling arthropods in crop fields has been attempted through modified agricultural practices, with positive results in several cases (Stinner \& House, 1990; Nentwig et al., 1998). Thus, ground-dwelling predatory species can be of substantive economic significance in agricultural systems.

The growing worldwide deployment of Bacillus thuringiensis (Bt) transgenic crops may impose risks on communities of ground-dwelling arthropods. Predatory arthropods on the ground may have direct contact with activated Bt toxins released into the rhizosphere through plant root exudates and decaying plant material (Saxena et al., 1999; Zwahlen et al., 2003; Baumgarte \& Tebbe, 2005). They may be exposed to toxin through prey that are able to acquire and convey toxins to predators (Saxena \& Stotzky, 2001) and may be indirectly impacted through the changes in the herbivore community that serves as the prey base. Despite debates over the amount of Bt toxins that accumulate and remain active in the soil during and after the crop season, and the adequacy of methods used in such studies (Sims 8 Holden, 1996; Sims \& Ream, 1997; Head et al., 2002; Hopkins \& Gregorich, 2003; Zwahlen et al., 2003), the results indicate clear differences between laboratory and field experiments. The degradation of the toxin synthesised by plants is expected to co-occur with plant decomposition, which can take days to months depending on environmental conditions, and contact with ground-dwelling species during this period is likely and has been demonstrated (Harwood et al., 2005; Zwahlen \& Andow, 2005).

Ground-dwelling arthropods are considered to be important not only for insect pest management but also for managing weeds and other organisms competing with cultivated crops (Stinner \& House, 1990; Ball \& Bousquet, 2001; Tooley $\&$ Brust, 2002); use of Bt transgenic crops can benefit ground-dwelling arthropods by reducing the use of broad-spectrum insecticides. For example, planting Bt potatoes led to increased abundance of ground-dwelling, generalist predator carabids and staphylinids and of araneids in the plant canopy when compared with conventional potato fields treated with broad-spectrum insecticides (Hoy et al., 1998; Reed et al., 2001). On the other hand, Bt toxin may negatively affect epigeal predators through contaminated prey and/or through plants and their products. The omnivorous feeding behaviour of ground-dwelling arthropods can bring them into contact with prey conveying Bt toxin (Saxena \& Stotzky, 2001; Zwahlen \& Andow, 2005) or with decaying plant material containing the toxin.

Transgenic Bt cotton is completing one decade since the initiation of grower use. Since 1996, the first season of Bt cotton in grower fields, it has been extensively planted across the US Cotton Belt, with more than $58 \%$ of 5.85 million hectares of cotton cultivated with Bt transgenic varieties in 2004 (NASS, 2004). Planting transgenic cotton expressing CrylAc toxin from Bacillus thuringiensis (Berliner) to manage the bollworm complex (Helicoverpa, Heliothis and Pectinophora) has resulted in reduced insecticide use, with direct benefits to growers and the environment (Betz et al., 2000). Introduction of Bt transgenic varieties coincided with successful eradication of the boll weevil, Anthonomus grandis Boheman, throughout the southeastern USA, which contributed to a significant reduction in insecticide use in the region. In Georgia, insecticide was applied to cotton 15-18 times per season prior to boll weevil eradication and was reduced to 4-6 applications after eradication (J. R. R., personal observation). Since the introduction of $\mathrm{Bt}$ transgenic varieties, the number of insecticide applications further declined to two to four per season, averaging 2.5 per season (J. R. R., personal observation). Nevertheless, transgenic plants have evoked many questions concerning possible direct and indirect effects on nontarget organisms.

The primary objective of this survey was to determine if Bt cotton and non-Bt cotton, cultivated and managed according to standard grower agricultural practices, support similar abundance, dynamics and diversity of important ground-dwelling arthropod predators. The abundance and diversity of the ground-dwelling arthropod communities in cotton fields present a challenge to selecting an ecologically representative species or group. Therefore in this study, we surveyed a range of taxa, including carabids, cicindelines, staphylinids, dermapterans, heteropterans and araneids - all of which include predators of interest for pest management in cotton. We used commercial cotton fields representative of the size and agronomic practices for the region as the ultimate system to realistically evaluate impacts of transgenic crops on nontarget organisms (Marvier, 2002; O'Callaghan et al., 2005).

\section{Materials and methods}

\section{Site description and crop management}

This study was conducted from 2002 to 2004 in grower fields cultivated with standard agricultural practices and located near Tifton, in southern Georgia, USA. The region is comprised of a mixed mosaic of agricultural habitats and forest remnants. Three pairs of Bt (DPL 458 or DPL 555) and non-Bt cotton (DPL 491) fields, from 5.5 to 15.0 hectares each, were monitored each season. Each pair of fields was separated from the others by 3.2 to $27 \mathrm{~km}$, between the coordinates $31^{\circ} 39^{\prime} \mathrm{N}, 83^{\circ} 54^{\circ} \mathrm{W}$ and $31^{\circ} 51^{\prime} \mathrm{N}, 83^{\circ} 55^{\prime} \mathrm{W}$. 
At each location, adjacent fields of Bt and non-Bt cotton were separated from one another by either a water ditch or a field road, and roads separated the study fields from adjacent crops such as peanut, tobacco and watermelon. All fields were planted during the first or second week of May each year and received preventative in-furrow treatments to suppress thrips [aldicarb $560 \mathrm{~g}(\mathrm{AI}) \mathrm{ha}^{-1}$ ] and foliar insecticide applications as needed during the season to control bollworms [Helicoverpa zea (Boddie) and Heliothis virescens (Fabr.)], stinkbugs and whiteflies. The Bt cotton varieties used in the study express the Cryl Ac toxin that targets only lepidopteran larvae. The toxin provides absolute control of $H$. virescens and very good control of $H$. zea and a number of other lepidopterans. Based on scouting data, non-Bt fields received insecticide applications to control bollworms, and both Bt and nonBt fields were treated to control stinkbugs late in the season (Table 1). The non-Bt cotton field at Chula was treated twice for bollworms within 15 days in July 2003 because of rainfall immediately after the first application. The frequency of rain during July 2003 caused variation in dates and frequency of sprays applied to each field.
In 2004, after a 1-year rotation with tobacco in Marchant, the selected Bt and non-Bt fields returned to the same locations used in 2002, only changing crop arrangement inside the cultivated areas. The Chula fields remained in the same location all three seasons, but study fields were rotated inside a cultivated area of approximately 40 ha surrounded by forest remnants. The third pair of fields (Ty Ty, Old House and Frazier) was set in different locations each season.

\section{Sampling of ground-dwelling arthropods}

A convenient pitfall trap was made using 500-ml plastic cups $\left(9-\mathrm{cm}\right.$ diameter $\times 12-\mathrm{cm}$ depth) $\left(\right.$ Solo $^{\circledR} \mathrm{P}-16$, Solo Cup Company, Urbana, IL, USA). On each side of the cup, we made two holes of 2-cm diameter approximately $5 \mathrm{~cm}$ from the bottom and covered with mesh in order to drain excess water resulting from irrigation or rainfall. As retention liquid, we used water mixed with Tween 20 at $0.2 \%$ to break surface tension, and as preservative, we used four to five pellets per cup of Diamond Crystal ${ }^{\circledR}$ water softener salt (Cargil Co., Minneapolis, MN, USA). Each pitfall cup was installed inside a larger and deeper

Table 1 Time and insecticide applied to manage pest infestations in Bt and non-Bt cotton fields near Tift County, GA, USA, during 2002-04

\begin{tabular}{|c|c|c|c|}
\hline Dates (Fields) & Non-Bt Cotton & Bt Cotton & Targeted Pest ${ }^{a}$ \\
\hline \multicolumn{4}{|l|}{2002} \\
\hline At planting & Aldicarb 15G (560 $\left.\mathrm{g} \mathrm{ha}^{-1}\right)^{\mathrm{b}}$ & Aldicarb 15G (560 $\left.\mathrm{g} \mathrm{ha}^{-1}\right)$ & Thrips \\
\hline 8-9 July $(C, M, T)$ & Spinosad (100 $\left.\mathrm{g} \mathrm{ha}^{-1}\right)$ & - & Heliothines \\
\hline 10-12 August (C, M) & $\begin{array}{l}\text { Lambda-cyhalothrin }\left(34 \mathrm{~g} \mathrm{ha} \mathrm{h}^{-1}\right)+ \\
\text { thiodicarb }\left(680 \mathrm{~g} \mathrm{ha}^{-1}\right)\end{array}$ & - & Heliothines \\
\hline 14 August (T) & - & Dicrotophos (390 $\mathrm{g} \mathrm{ha}^{-1}$ ) & Stinkbugs \\
\hline 5-7 September (C, M) & Pyriproxifen (60 $\mathrm{g} \mathrm{ha}^{-1}$ ) & Pyriproxifen (60 $\mathrm{g} \mathrm{ha}^{-1}$ ) & Whiteflies \\
\hline \multicolumn{4}{|l|}{2003} \\
\hline At planting & Aldicarb $15 \mathrm{G}\left(560 \mathrm{~g} \mathrm{ha}^{-1}\right)$ & Aldicarb 15G (560 g ha ${ }^{-1}$ ) & Thrips \\
\hline 8 July (0) & Spinosad (100 $\mathrm{g} \mathrm{ha}^{-1}$ ) & - & Heliothines \\
\hline 13 July (M) & Spinosad (100 $\left.\mathrm{g} \mathrm{ha}^{-1}\right)$ & - & Heliothines \\
\hline 14 July (C) & Lambda-cyhalothrin (30 $\mathrm{g} \mathrm{ha}^{-1}$ ) & - & Heliothines \\
\hline 21 July (C) & Lambda-cyhalothrin (45 $\mathrm{g} \mathrm{ha}^{-1}$ ) & - & Heliothines \\
\hline 3-5 August (M, O) & Lambda-cyhalothrin (45 $\mathrm{g} \mathrm{ha}^{-1}$ ) & - & Heliothines + stinkbugs \\
\hline 30 August $(0)^{a}$ & Bifenthrin (70 $\left.\mathrm{g} \mathrm{ha}^{-1}\right)$ & Bifenthrin (70 $\left.\mathrm{g} \mathrm{ha}^{-1}\right)$ & Stinkbugs \\
\hline \multicolumn{4}{|l|}{2004} \\
\hline At planting & Aldicarb 15G (560 $\left.\mathrm{g} \mathrm{ha}^{-1}\right)$ & Aldicarb 15G (560 g ha ${ }^{-1}$ ) & Thrips \\
\hline 2-7 July (C, M, F) & Lambda-cyhalothrin (45 $\mathrm{g} \mathrm{ha}^{-1}$ ) & - & Heliothines \\
\hline 15 July $(C, M)$ & Spinosad (100 $\left.\mathrm{g} \mathrm{ha}^{-1}\right)$ & - & \\
\hline 29 July (C) & - & Dicrotophos (420 $\mathrm{g} \mathrm{ha}^{-1}$ ) & Stinkbugs \\
\hline 5 August $(\mathrm{C})$ & Zeta-cypermethrin (160 $\left.\mathrm{g} \mathrm{ha}^{-1}\right)$ & - & Heliothines + stinkbugs \\
\hline 17 August (M, F) & Zeta-cypermethrin (210 $\mathrm{g} \mathrm{ha}^{-1}$ ) & Zeta-cypermethrin (210 $\mathrm{g} \mathrm{ha}^{-1}$ ) & Heliothines + stinkbugs \\
\hline 31 August $(M)^{a}$ & - & Acephate (810 $\mathrm{g} \mathrm{ha}^{-1}$ ) & Stinkbugs \\
\hline
\end{tabular}

Bt, Bacillus thuringiensis; C, Chula; F, Frazier fields; M, Marchant; O, Old House; T, Ty Ty.

a Insecticide application after terminating experimental sampling; Thrips (Frankliniella occidentalis, Frankliniella fusca and Thrips tabaci), Heliothine (Helicoverpa zea and Heliothis virescens) and Stinkbugs (Nezara viridula and Euschistus servus). Thrips threshold (preventative treatment); Heliothine threshold, $8-10 \%$ of plants with eggs or small larvae on terminals; stinkbug threshold, $18-20 \%$ bolls of $\sim 2.5 \mathrm{~cm}$ diameter with internal damage; whitefly threshold, plants infested and honeydew on plants (Guillebeau, 2004).

${ }^{b}$ Rate in grams of active ingredient per hectare. 
plastic base cup (10-cm diameter $\times 15-\mathrm{cm}$ depth) $($ Packer Ware $^{\circledR}$, Lawrence, KS, USA) that had no bottom to permit drainage and had been installed previously across the fields. The pitfall cups and their bases were built so that the pitfall cups fit snugly inside the base cup, with the rim of the lining cup held in place slightly below the top edge of the base cup. The upper edge of the base cup was level with the soil surface. Twenty traps were set up from border to border of all fields in 10 equally spaced, prefixed stations with two traps each. The sampling stations were set up immediately after seedling emergence. The first sampling station was set at the fifth cotton row from the border. At each station, two traps were installed within cotton rows and with five rows between traps at the same station. The distance between stations varied as a function of field size. The traps were collected weekly (ca 1 week of exposure) by replacing the cups and using the same base throughout the season. Collected traps were returned to the laboratory, where the contents were washed, removed and stored in 20-ml scintillation vials containing $70 \%$ ethanol. The data presented will focus on species representative of arthropod communities relevant to pest management of cotton in the region (e.g. carabids, cicindelines, dermapterans, staphylinids, heteropterans and araneids).

\section{Species identification and statistical analysis}

In the laboratory, specimens were sorted into morphospecies, and all adult insects were identified to order, family and species as possible. Identification of dermapterans to species was based on Hoffman (1987). Lindroth (19611969), Ciegler (2000), the University of Georgia Collection of Arthropods (UGCA), Athens (GA) and the Florida State Collection of Arthropods, Gainesville (FL) were used to identify carabid species; species nomenclature followed Ciegler (2000). Functional group designation of carabid species (carnivore or phytophage) was based on predominant feeding behaviour reported in the literature (Table 2). Cicindelinae were identified to species based on Knisley \& Schultz (1997), araneids were identified to species with Kaston (1978) and Breene et al. (1993) and Staphylinidae were only sorted to family level. The vials containing the collected material were deposited at the Biological Control Laboratory (University of Georgia-Coastal Plain Experiment Station), in Tifton, GA, and voucher specimens were deposited at the UGCA, Athens, GA.

Prior to analysis, data from individual pitfall traps were pooled within each week and for each field. These totals were standardised as the number of individuals per pitfall trap recovered out of 20 traps per week and per field, discarding traps lost to flooding or other destructive event and therefore comprising three replications (i.e. fields) for each sampling week. Year-long averages were generated from each weekly average over the number of sample weeks per year ( 10 weeks in 2002 and 11 weeks in 2003 and 2004). Because the questions of interest were related to overall changes in the species community in Bt cotton relative to non-Bt cotton fields, species were pooled to higher identified taxa (i.e. carabids, cicindelines, dermapterans, araneids, staphylinids and heteropterans). The data for each taxon were analysed through six independent repeated measures analyses of variance (ANOVA) comparing cotton types within year and across 3 years, which also avoided violation of ANOVA assumptions by considering species occurring only at very low densities. All data were $\log (x+1)$ transformed prior to univariate analyses but untransformed averages are presented. The results were submitted to one-way repeated measures ANOVA, with repeated measures on sample weeks within year using fields as a blocking factor because the arthropod sampling was conducted on the same fields over the year. These analyses were carried out using the Proc ANOVA of SAS (SAS Institute, 1999-2001), adapting the PROFILE statement, as suggested by Cody \& Smith (1997). For analyses across 3 years, data within year were averaged per year and submitted to ANOVA using the Proc MIXED of SAS (SAS Institute, 1999-2001), with year as a random effect and cotton type as a fixed effect.

Because unequal numbers of pitfall traps were evaluated in each sample period, species accumulation curves were generated to assess the effect of sampling effort (10 weeks in 2002 and 11 weeks each in 2003 and 2004) and numbers of individuals collected (i.e. abundance) on species richness results, allowing comparisons of Bt and non-Bt cotton fields. The software program EstimateS (Colwell, 2004) was used to calculate species accumulation curves for the whole community - species richness through a Jackknife estimator and diversity using the Shannon $\left(\mathrm{H}^{\prime}\right)$ and Simpson's indices for each field within each season (ca 18 estimations: 9 Bt fields and 9 non-Bt fields), involving 100 randomisations of the samples (Colwell, 2004).

Changes in species abundance of the ground-dwelling community were investigated using multivariate analysis through principal response curves (PRC) and considering each taxon collected in Bt cotton fields relative to non-Bt cotton, which was designated as the control. PRC analysis is a multivariate technique derived from redundancy analysis (RDA) that focuses on the proportion of the variance in variables of interest (in this case, ground-dwelling species of economic interest for pest management collected in Bt cotton field on all sampling weeks throughout the cotton season) explainable by the independent variable, cotton type. Parameters of the PRC were generated using 
Table 2 Totals and means per pitfall trap (Bt = 1569 traps and non-Bt = 1501 traps), functional group, abundance and diversity indices of grounddwelling arthropods collected in three pairs of Bt and non-Bt commercial cotton fields during the season 2002 ( $n=10$ sampling weeks) and 2003 and 2004 ( $n=11$ sampling weeks), Tift County, GA, USA

\begin{tabular}{|c|c|c|c|c|c|c|c|c|c|c|}
\hline \multirow[b]{2}{*}{ Taxa } & \multirow[b]{2}{*}{ Group $^{a}$} & \multicolumn{3}{|l|}{2002} & \multicolumn{3}{|l|}{2003} & \multicolumn{3}{|l|}{2004} \\
\hline & & $n$ & $\mathrm{Bt}$ & Non-Bt & $n$ & $\mathrm{Bt}$ & Non-Bt & $n$ & $\mathrm{Bt}$ & Non-Bt \\
\hline \multicolumn{11}{|l|}{ Araneae } \\
\hline \multicolumn{11}{|l|}{ Clubionidae } \\
\hline $\begin{array}{l}\text { Castianeira nr. floridana } \\
\text { Corinidae }\end{array}$ & $C^{1}$ & 70 & 0.11 & 0.12 & 5 & 0.003 & 0.005 & 9 & 0.006 & 0.009 \\
\hline $\begin{array}{l}\text { Falconia gracilis (Keyserling) } \\
\text { Lycosidae }\end{array}$ & \multicolumn{10}{|c|}{ Lycosidae } \\
\hline Hogna sp. & $C^{1}$ & 15 & 0.017 & 0.016 & 7 & 0.006 & 0.004 & 13 & 0.012 & 0.008 \\
\hline Pardosa milvina (Hentz) & $C^{1}$ & 26 & 0.027 & 0.033 & 35 & 0.030 & 0.030 & 110 & 0.110 & 0.068 \\
\hline $\begin{array}{l}\text { Pardosa pauxilla } \\
\text { Montgomery }\end{array}$ & \multicolumn{9}{|c|}{ Montgomery } & 0.250 \\
\hline \multicolumn{10}{|l|}{ Oxyopidae } & 0.016 \\
\hline $\begin{array}{l}\text { Oxyopes salticus Hentz } \\
\text { Salticidae }\end{array}$ & $C^{1}$ & 14 & 0.017 & 0.022 & 8 & 0.002 & 0.016 & 0 & - & - \\
\hline $\begin{array}{l}\text { Habronattus } \\
\text { coecatus (Hentz) }\end{array}$ & $C^{1}$ & 19 & 0.021 & 0.032 & 7 & 0.011 & 0.003 & 26 & 0.025 & 0.016 \\
\hline \multicolumn{11}{|l|}{ Tetragnathidae } \\
\hline $\begin{array}{l}\text { Tetragnatha } \\
\text { laboriosa Hentz }\end{array}$ & $C^{1}$ & 0 & - & - & 0 & - & - & 1 & 0.002 & 0 \\
\hline \multicolumn{11}{|l|}{ Therediidae } \\
\hline $\begin{array}{l}\text { Lactrodectus sp. } \\
\text { Thomisidae }\end{array}$ & $C^{1}$ & 8 & 0.006 & 0.012 & 0 & - & - & 0 & - & - \\
\hline Xysticus sp. & $C^{1}$ & 3 & 0.005 & 0.002 & 0 & - & - & 1 & 0 & 0.002 \\
\hline \multicolumn{11}{|l|}{ Dermaptera } \\
\hline $\begin{array}{l}\text { Doru taeniatum (Dohorn) } \\
\text { Carcinophoridae }\end{array}$ & $C^{2}$ & 6 & 0.005 & 0.017 & 5 & 0.001 & 0.007 & 23 & 0.033 & 0.004 \\
\hline $\begin{array}{l}\text { Euborellia annulipes (Lucas) } \\
\text { Labiduridae }\end{array}$ & $C^{2}$ & 97 & 0.13 & 0.11 & 2 & 0 & 0.006 & 56 & 0.036 & 0.065 \\
\hline Labidura riparia (Pallas) & $c^{2}$ & 2329 & 3.66 & 3.49 & 367 & 0.04 & 0.22 & 2406 & 2.447 & 1.547 \\
\hline \multicolumn{11}{|l|}{ Coleoptera } \\
\hline $\begin{array}{l}\text { Staphylinidae } \\
\text { Cicindelinae }\end{array}$ & & 134 & 0.19 & 0.13 & 200 & 0.181 & 0.206 & 356 & 0.196 & 0.419 \\
\hline $\begin{array}{l}\text { Megacephala } \\
\text { carolina Linnaeus }\end{array}$ & $c^{3}$ & 4654 & 4.59 & 4.56 & 6903 & 6.755 & 5.207 & 13524 & 11.877 & 10.462 \\
\hline Cicindela punctulata Oliver & $c^{3}$ & 259 & 0.21 & 0.29 & 156 & 0.112 & 0.157 & 157 & 0.157 & 0.104 \\
\hline $\begin{array}{l}\text { Megacephala } \\
\text { virginica Linnaeus }\end{array}$ & $C^{3}$ & 21 & 0.20 & 0.018 & 99 & 0.071 & 0.108 & 73 & 0.054 & 0.071 \\
\hline \multicolumn{11}{|l|}{ Carabidae } \\
\hline Acupalpus testaceus Dejean & $C^{5}$ & 0 & - & - & 0 & - & - & 30 & 0.024 & 0.023 \\
\hline Agonum aeruginosum Dejean & $U$ & 0 & - & - & 0 & - & - & 1 & 0.002 & 0 \\
\hline Amara crupeolata Putzeys & $P^{4,5}-C^{5}$ & 10 & 0.008 & 0.009 & 3 & 0.002 & 0.004 & 10 & 0.005 & 0.011 \\
\hline Amara impuncticolis (Say) & $P^{5}-C^{5,12}$ & 0 & - & - & 10 & 0.007 & 0.103 & 6 & 0.008 & 0.004 \\
\hline Amara sp. & $?$ & 26 & 0.012 & 0.018 & 19 & 0.017 & 0.015 & 10 & 0.005 & 0.015 \\
\hline $\begin{array}{l}\text { Anisodactylus merula } \\
\text { (Germar) }\end{array}$ & $C^{5}-P^{5}$ & 12 & 0.019 & 0.005 & 50 & 0.023 & 0.064 & 132 & 0.077 & 0.014 \\
\hline Apenes sinuatus (Say) & $U$ & 0 & - & - & 1 & 0.002 & 0 & 0 & - & - \\
\hline Apristus latens (LeConte) & $U$ & 230 & 0.16 & 0.32 & 88 & 0.092 & 0.076 & 129 & 0.161 & 0.048 \\
\hline $\begin{array}{l}\text { Ardistomis schaumii } \\
\text { LeConte }\end{array}$ & $U$ & 0 & - & - & 0 & - & - & 2 & 0.003 & - \\
\hline $\begin{array}{l}\text { Aspidoglossa } \\
\text { subangulata (Claudoir) }\end{array}$ & $P^{5}$ & 0 & - & - & 1 & 0.002 & 0 & 0 & - & - \\
\hline
\end{tabular}


Table 2 Continued

\begin{tabular}{|c|c|c|c|c|c|c|c|c|c|c|}
\hline \multirow[b]{2}{*}{ Taxa } & \multirow[b]{2}{*}{ Group $^{a}$} & \multicolumn{3}{|c|}{2002} & \multicolumn{3}{|l|}{2003} & \multicolumn{3}{|c|}{2004} \\
\hline & & $n$ & $\mathrm{Bt}$ & Non-Bt & $n$ & $\mathrm{Bt}$ & Non-Bt & $n$ & $\mathrm{Bt}$ & Non-Bt \\
\hline $\begin{array}{l}\text { Bembidion semistriatum } \\
\text { (Haldeman) }\end{array}$ & U & 2 & 0 & 0.002 & 0 & - & - & 0 & - & - \\
\hline Calleida decora (Fabricius) & $c^{5}$ & 1 & 0.008 & 0 & 0 & - & - & 3 & 0 & 0.005 \\
\hline Calosoma sayi Dejean & $C^{5}$ & 16 & 0.018 & 0.003 & 41 & 0.012 & 0.063 & 26 & 0.033 & 0.009 \\
\hline $\begin{array}{l}\text { Calosoma scrutator } \\
\text { (Fabricius) }\end{array}$ & $C^{5}$ & 1 & 0 & 0.002 & 0 & - & - & 0 & - & - \\
\hline Chlaenius aestivus Say & $C^{8}$ & 8 & 0.008 & 0.014 & 5 & 0.004 & 0.007 & 2 & 0.003 & 0 \\
\hline $\begin{array}{l}\text { Chlaenius sericeus } \\
\text { sericeus (Foster) }\end{array}$ & $C^{5}$ & 0 & - & - & 0 & - & - & 1 & 0.002 & 0 \\
\hline Chlaenius tricolor Dejean & $C^{5,8}$ & 0 & - & - & 5 & 0.003 & 0.005 & 0 & - & - \\
\hline Clivina americana Dejean & $U$ & 0 & - & - & 0 & - & - & 3 & 0.003 & 0.001 \\
\hline Clivina bipustulata (Fabricius) & U & 2 & 0.010 & 0 & 13 & 0.015 & 0.009 & 0 & - & - \\
\hline Clivina sp. & $?$ & 1 & 0.002 & 0 & 0 & - & - & 0 & - & - \\
\hline Dicaelus elongatus Bonelli & $C^{5}$ & 0 & - & - & 0 & - & - & 1 & 0 & 0.002 \\
\hline Dyschirius filiformis LeConte & $U$ & 0 & - & - & 2 & 0.005 & 0 & 5 & 0.005 & 0.003 \\
\hline $\begin{array}{l}\text { Dyschirius haemorrhoidalis } \\
\text { (Dejean) }\end{array}$ & $U$ & 1 & 0.002 & - & 0 & - & - & 0 & - & - \\
\hline Euryderys grossus Say & $P^{5,8}$ & 1 & 0 & 0.012 & 0 & - & - & 0 & - & - \\
\hline Galerita bicolor Drury & $c^{5}$ & 0 & - & - & 0 & - & - & 2 & 0.002 & 0 \\
\hline $\begin{array}{l}\text { Harpalus caliginosus } \\
\text { (Fabricius) }\end{array}$ & $C^{5}-P^{5,8}$ & 10 & 0.018 & 0.013 & 6 & 0.008 & 0.005 & 6 & 0.005 & 0.006 \\
\hline Harpalus gravis LeConte & U & 9 & 0.015 & 0.013 & 520 & 0.621 & 0.358 & 20 & 0.022 & 0.011 \\
\hline $\begin{array}{l}\text { Harpalus pennsylvanicus } \\
\text { (De Geer) }\end{array}$ & $C^{5}-P^{5}$ & 25 & 0.031 & 0.025 & 10 & 0.003 & 0.019 & 6 & 0.009 & 0 \\
\hline Lebia analis Dejean & $C^{5}$ & 0 & - & - & 1 & 0.002 & - & 1 & 0.002 & 0 \\
\hline Lebia ornata Say & $c^{5}$ & 0 & - & - & 1 & 0 & 0.002 & 0 & - & - \\
\hline Lebia viridis Say & $C^{2}$ & 6 & 0.010 & 0.006 & 0 & - & & 0 & - & - \\
\hline $\begin{array}{l}\text { Leptotrachelus } \\
\text { dorsalis (Fabricius) }\end{array}$ & $C^{5}$ & 0 & - & - & 0 & - & - & 3 & 0.002 & 0.003 \\
\hline $\begin{array}{l}\text { Loxandrus velocipes } \\
\text { Casey }\end{array}$ & U & 2 & 0.005 & 0 & 0 & - & - & 0 & - & - \\
\hline $\begin{array}{l}\text { Morion monilicornis } \\
\text { (Latreille) }\end{array}$ & U & 1 & 0 & 0.002 & 0 & - & - & 0 & - & - \\
\hline $\begin{array}{l}\text { Nemotarsus elegans } \\
\text { LeConte }\end{array}$ & U & 0 & - & - & 1 & 0.002 & - & 0 & - & - \\
\hline Platynus decentis (Say) & $C^{5}$ & 0 & - & - & 1 & 0 & 0.002 & 0 & - & - \\
\hline $\begin{array}{l}\text { Scarites quadriceps } \\
\quad \text { Claudoir }\end{array}$ & $C^{6}$ & 0 & - & - & 0 & - & - & 3 & 0 & 0.005 \\
\hline $\begin{array}{l}\text { Scarites subterraneus } \\
\text { Fabricius }\end{array}$ & $C^{5}-P^{8}$ & 2 & 0.005 & 0 & 0 & - & - & 0 & - & - \\
\hline $\begin{array}{l}\text { Selenophorus } \\
\text { palliatus (Fabricius) }\end{array}$ & $P^{7}$ & 679 & 0.66 & 0.94 & 1669 & 1.99 & 1.15 & 323 & 0.28 & 0.26 \\
\hline Semiardistomis viridis (Say) & U & 0 & - & - & 0 & - & - & 1 & 0.002 & 0 \\
\hline Stenolophus conjunctus (Say) & $c^{5}$ & 0 & - & - & 1 & 0 & 0.002 & 0 & - & - \\
\hline Stenolophus ochropezus (Say) & $C^{9,12}-P^{5}$ & 5 & 0.010 & 0.10 & 13 & 0.008 & 0.020 & 10 & 0.012 & 0.006 \\
\hline $\begin{array}{l}\text { Tetragonoderus } \\
\text { fasciatus (Haldeman) }\end{array}$ & $U$ & 6 & 0.007 & 0.004 & 0 & - & - & 0 & - & - \\
\hline $\begin{array}{l}\text { Tetragonoderus } \\
\text { intersectus (Germar) }\end{array}$ & $U$ & 31 & 0.032 & 0.044 & 43 & 0.026 & 0.044 & 20 & 0.008 & 0.029 \\
\hline \multicolumn{11}{|l|}{ Heteropteran } \\
\hline Geocoris punctipes (Say) & $C^{10}$ & 65 & 0.064 & 0.082 & 24 & 0.016 & 0.030 & 55 & 0.032 & 0.052 \\
\hline Geocoris uliginosus (Say) & $C^{10}$ & 94 & 0.092 & 0.105 & 16 & 0.012 & 0.012 & 243 & 0.164 & 0.245 \\
\hline
\end{tabular}


Table 2 Continued

\begin{tabular}{|c|c|c|c|c|c|c|c|c|c|c|}
\hline \multirow[b]{2}{*}{ Taxa } & \multirow[b]{2}{*}{ Group $^{a}$} & \multicolumn{3}{|l|}{2002} & \multicolumn{3}{|l|}{2003} & \multicolumn{3}{|l|}{2004} \\
\hline & & $n$ & $\mathrm{Bt}$ & Non-Bt & $n$ & $\mathrm{Bt}$ & Non-Bt & $n$ & $\mathrm{Bt}$ & Non-Bt \\
\hline \multicolumn{11}{|l|}{ Nabidae } \\
\hline Nabis spp. & $C^{11}$ & 17 & 0.024 & 0.017 & 233 & 0.151 & 0.272 & 12 & 0.004 & 0.017 \\
\hline $\begin{array}{l}\text { Total/seasonal } \\
\text { mean per trap }\end{array}$ & & 9631 & $\begin{array}{l}11.4 \\
(7.8-15.1)^{\mathrm{b}}\end{array}$ & $\begin{array}{l}11.5 \\
(8.4-14.6)\end{array}$ & 11069 & $\begin{array}{l}11.7 \\
(8.9-14.5)\end{array}$ & $\begin{array}{l}9.1 \\
(6.5-13.1)\end{array}$ & 18280 & $\begin{array}{l}16.3 \\
(13.0-19.6)\end{array}$ & $\begin{array}{l}14.0 \\
(10.5-17.3)\end{array}$ \\
\hline $\begin{array}{l}\text { Total species richness } \\
\text { (Jackknife estimator) }\end{array}$ & & & $\begin{array}{l}37.5 \\
(34.3-40.7)\end{array}$ & $\begin{array}{l}39.0 \\
(35.5-42.5)\end{array}$ & & $\begin{array}{l}37.9 \\
(35.4-40.4)\end{array}$ & $\begin{array}{l}37.5 \\
(34.9-40.1)\end{array}$ & & $\begin{array}{l}36.9 \\
(34.6-39.2)\end{array}$ & $\begin{array}{l}38.4 \\
(34.6-42.2)\end{array}$ \\
\hline Diversity $\left(H^{\prime}\right)$ index & & & $\begin{array}{l}1.42 \\
(0.92-1.91)\end{array}$ & $\begin{array}{l}1.56 \\
(1.37-1.74)\end{array}$ & & $\begin{array}{l}1.28 \\
(0.40-2.15)\end{array}$ & $\begin{array}{l}1.55 \\
(0.83-2.26)\end{array}$ & & $\begin{array}{l}1.03 \\
(0.39-1.67)\end{array}$ & $\begin{array}{l}1.01 \\
(0.33-1.68)\end{array}$ \\
\hline Simpson's index & & & $\begin{array}{l}2.47 \\
(1.99-2.96)\end{array}$ & $\begin{array}{l}2.80 \\
(2.14-3.46)\end{array}$ & & $\begin{array}{l}2.41 \\
(2.20-2.62)\end{array}$ & $\begin{array}{l}2.78 \\
(2.19-3.37)\end{array}$ & & $\begin{array}{l}1.88 \\
(1.62-2.14)\end{array}$ & $\begin{array}{l}2.05 \\
(1.63-2.47)\end{array}$ \\
\hline
\end{tabular}

Bt, Bacillus thuringiensis.

${ }^{a}$ Functional group based on predominant feeding behaviour as carnivorous $(C)$, phytophagous (P), unknown (U) and respective reference source: ${ }^{1}$ Breene et al. (1993), ${ }^{2}$ Hoffman (1987), ${ }^{3}$ Knisley \& Schultz (1997), ${ }^{4}$ Johnson \& Cameron (1969), ${ }^{5}$ Larochelle \& Larivière (2003), ${ }^{6}$ Best \& Beegle (1977), ${ }^{7}$ Lindroth (1961-1969), ${ }^{8}$ Ball \& Bousquet (2001), ${ }^{9}$ Jo \& Smitley (2003), ${ }^{10}$ Crocker \& Whitcomb (1980), ${ }^{11}$ Lattin (1989), ${ }^{12}$ Frank \& Shrewsbury (2004) and ${ }^{12}$ Bonaldo (2000).

${ }^{b}$ Values between parentheses stand for $95 \%$ confidence intervals of means from untransformed data, and $P$ values comparing mean abundance per trap within group between cotton types are offered in the text.

CANOCO 4.5 for Windows (Lepš \& Šmilauer, 2003) through RDA least-squares estimates. By plotting values of $c_{d t}$ for the treatment over sampling time, a PRC diagram is obtained that depicts species abundance changes in the community composition. We compared community abundance changes in Bt cotton fields with the non-Bt cotton community as our standard $\left(c_{d t}=0\right)$. For each set of analyses, the null hypothesis that the PRC does not explain significant treatment variance was tested using an F-type test obtained by permutating the whole time series in the partial RDA from which the PRC was obtained (Lepš \& Šmilauer, 2003). Random permutation through the Monte-Carlo method (999 permutations) was also performed for significant treatment PRCs using CANOCO 4.5 within each sampling date to test the null hypothesis that, on each sampling date, the principal response $c_{d t}$ did not differ significantly between cotton types. Abundance values (predator species per pitfall trap) were log transformed to reduce the effect of dominant species.

\section{Results}

\section{Seasonal patterns}

Numbers of carabids captured gradually declined throughout the growing season (one-way repeated measures ANOVA, $F_{10,40}=19.08 ; P<0.0001$ ) but did so equally between $\mathrm{Bt}$ and non-Bt cotton fields $\left(F_{1,} 4=0.32\right.$, $P=0.6027)$, and there were no cotton and year interactions $\left(F_{2,8}=0.22, P=0.8049\right)$. When only predatory carabids were considered, no changes in abundance were observed in any year over time (sampling week effect, $\left.F_{10}, 40=1.26 ; \quad P=0.2835\right)$, nor were differences ob- served between cotton types $\left(F_{1,4}=0.42, P=0.5529\right)$. Likewise, there was no significant interaction between cotton type and year $\left(F_{2,8}=0.00, P=0.9983\right)$. Cicindelines were more commonly collected in traps as June progressed, and their abundance declined significantly later (sampling week effect, $F_{10,40}=40.98 ; P<0.0001$ ) but equally between $\mathrm{Bt}$ and non-Bt cotton fields $\left(F_{1,4}=0.40, P=0.5596\right)$ and with no interactions between cotton type and year $\left(F_{2,8}=0.273, P=0.5107\right)$. The other four taxa (dermapterans, araneids, staphylinids and heteropterans) were similarly abundant in both cotton types $(P>0.05)$, with high variability among sample weeks throughout each season. No pattern of abundance emerged for these taxa, except in the case of heteropterans $\left(F_{10,40}=3.0, \quad P=0.0064\right)$, which declined in number towards the end of the season.

\section{Ground-dwelling species abundance}

A total of 38980 ground-dwelling individuals, comprising 65 taxa of interest in cotton pest management, were collected across all seasons and fields during the study period. All the specimens were identified to species, except Staphylinidae, which were sorted only to family level. Species of geocorids, nabids, cicindelines and dermapterans were collected in all fields, as were the most abundant species of carabids and araneids (Table 2). Among the most abundant predatory ground-dwelling taxa (more than 510 individuals were collected in a single year), none was unique to cotton genotype or year, except one carabid, Acupalpus testaceus Dejean, that comprised 30 individuals collected only in 2004 but was found in both Bt and non-Bt cotton fields (Table 2). 
Seasonal averages for pitfall catches ranged from 9.1 to 16.3 ground-dwelling arthropods per trap per sample date across seasons and means always overlapped within 95\% confidence intervals between Bt and non-Bt cotton fields (Table 2). Therefore, there is no evidence for differences in relative numbers captured per trap or in predominant species within groups between $\mathrm{Bt}$ and non-Bt cotton fields.

With the exception of heteropterans and araneids, all other groups varied in abundance across seasons (season effect under mixed model of ANOVA). A significant effect of seasons on abundance of dermapterans was observed $\left(F_{2,12}=5.33, P=0.021\right)$, with relatively low numbers of the predominant species, Labidura riparia, trapped in 2003 compared with the other years. Likewise, numbers of cicindelines varied across seasons $\left(F_{2,12}=8.68, P=\right.$ 0.0047 ), with numbers of Megacephala carolina L. increasing late during 2004, similar to what was observed for staphylinids $\left(F_{2,12}=9.65, P=0.0032\right)$, which also were more abundant in 2004. All carabids, including predators and phytophagous species, tended to be trapped in greater numbers in $2003\left(F_{2,12}=5.54, P=0.0198\right)$, especially common species such as Selenophorus palliatus Fabr. and Harpalus gravis LeConte (Table 2). Because populations of each group varied differently in occurrence among seasons, the mean number of individuals captured per pitfall trap did not differ significantly with cotton type for any surveyed group within a season or over the three-season period.

Principal response curve analyses, in accordance with univariate analyses with higher taxa (Table 2), showed no statistically significant impact of Bt cotton compared with non-Bt cotton (the standard reference) on numbers of 65 taxa of ground-dwelling arthropods trapped in all 3 years pooled $(F=2.86, \quad P=0.922 ;$ Fig. 1$)$. Sample week (i.e. time) was the major contributor to variance in species abundance, with $73.8 \%$ of this variance explained by the first PRC axis. Although the second PRC axis explained an additional $11.2 \%$ of variance, the second PRC axis was not significant $(P>0.05)$. The interaction of sample week and cotton type explains $54.7 \%$ of the variance, whereas variance because of $\mathrm{Bt}$ cotton alone accounted for only $4.2 \%$. This result underscores the apparent lack of effect of Bt cotton on trap capture and dynamics of ground-dwelling arthropods in Bt relative to non-Bt cotton fields (Fig. 1). The contribution of each species to the community changes (response, $c_{d t}$ ) depicted by PRC diagrams also can be interpreted using the statistical weights $\left(b_{\mathrm{k}}\right)$ of each species shown on the right side of the diagram (Fig. 1). Species with high weight values are most likely to exhibit population patterns that correspond to the changes in abundance shown in the diagram, while low values contribute little to the overall community response, indicating a weak association or a response pattern different from that displayed in the diagram (Van den Brink \& Ter Braak, 1999). Thus, of the 65 taxa, only those that make relatively important statistical contributions are shown on the right side of the diagram.

\section{Experimental fields and species abundance and diversity}

The outcomes showed no significant effect of field area on number of species collected in either Bt $(r=0.12, P=0.7396)$ or non-Bt cotton fields $(r=-0.55$,

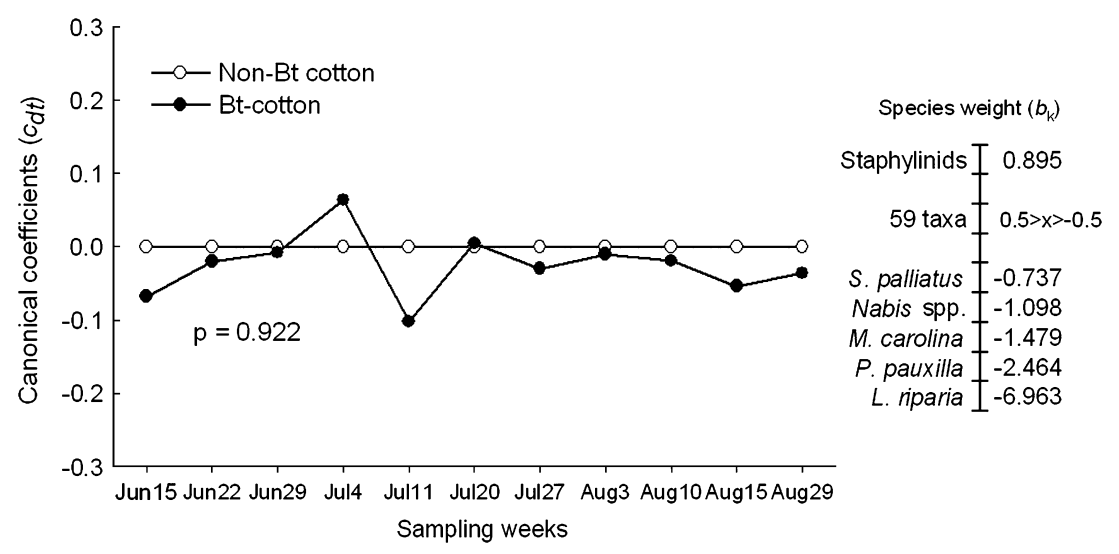

Figure 1 Principal response curves (PRC) and species weights for species numbers collected in pitfall trap throughout the cotton-growing seasons of 2002-04 in Tift County, GA. The PRC curve shows the main effect of Bacillus thuringiensis (Bt) cotton on predator community relative to non-Bt cotton $(y=0$ line). The $P$ value indicates significance of the PRC diagram over all sampling dates based on F-type permutation test. The higher the species weight, the more likely the actual response pattern of the species follows the pattern of the PRC. For a complete list of all species included in the analyses, see Table 2. 
$P=0.1178)$. Similarly, the number of species collected was not influenced by numbers of individuals collected in $\mathrm{Bt}(r=-0.05, \quad P=0.8972)$ or in non-Bt $(r=0.33, \quad P=0.3819)$ cotton fields. Also, the species numbers collected were not a function of the number of pitfall traps recovered from each field (Bt, $r=-0.17$, $P=0.6471$ and non-Bt, $r=0.16, P=0.6673)$. These results suggest no interaction between final sampling effort (i.e. number of pitfall traps recovered and the relative abundance and diversity of ground-dwelling predator arthropods sampled) and number of species sampled in each year and cotton type (Fig. 2). These results are supported by the species accumulation curves generated for each cotton type and year (Fig. 2). There is a clear trend in increase of total numbers of individuals collected among years (Table 2) and between Bt and non-Bt cotton fields in 2004 (Fig. 2). However, the increase in species accumulation was not a linear relationship with sampling weeks or abundance (i.e. individuals collected). Thus, increases in number of individuals collected until sampling week 10 reached a plateau and did not result in

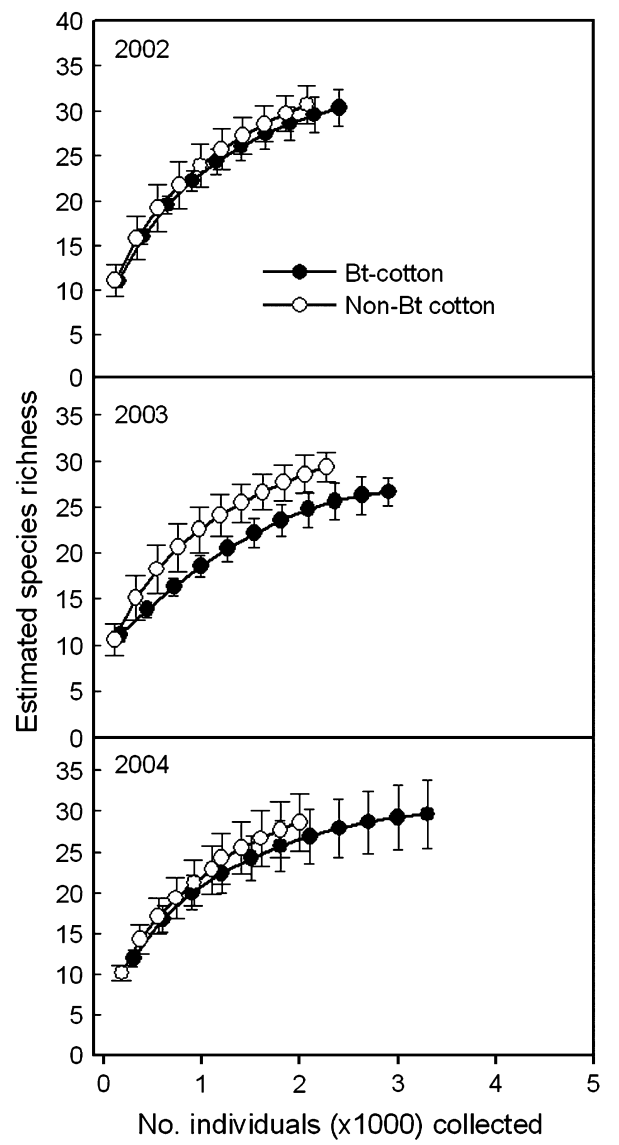

significant differences in species richness, which is clearly seen in re-scaling sampling efforts for sampling weeks (Gotelli \& Colwell, 2001). Moreover, the means of the estimated total species richness for the respective cotton types overlap within the $95 \%$ confidence intervals within seasons and across all years (Table 2).

Although 65 taxa of ground-dwelling arthropods were identified from family to species level, relatively few taxa comprised the majority of the trapped specimens (Table 2). Among araneids, Pardosa pauxilla Montgomery was the most commonly captured species, accounting for $68.5-85 \%$ of the 11 araneid species collected across years (Table 2). Cicindelinae and Dermaptera were chiefly represented by one species each, M. carolina and L. riparia, respectively, comprising $>94 \%$ of all collected individuals of cicindelines and dermapterans. For example, M. carolina comprised $48.3 \%$ of specimens of all taxa collected in 2002 and outnumbered all other taxa together $(>50 \%)$ in 2003 and 2004. Carabidae was the most speciose taxon, with 44 species collected, but only four species - S. palliatus Fabr., Apristus latens LeConte,

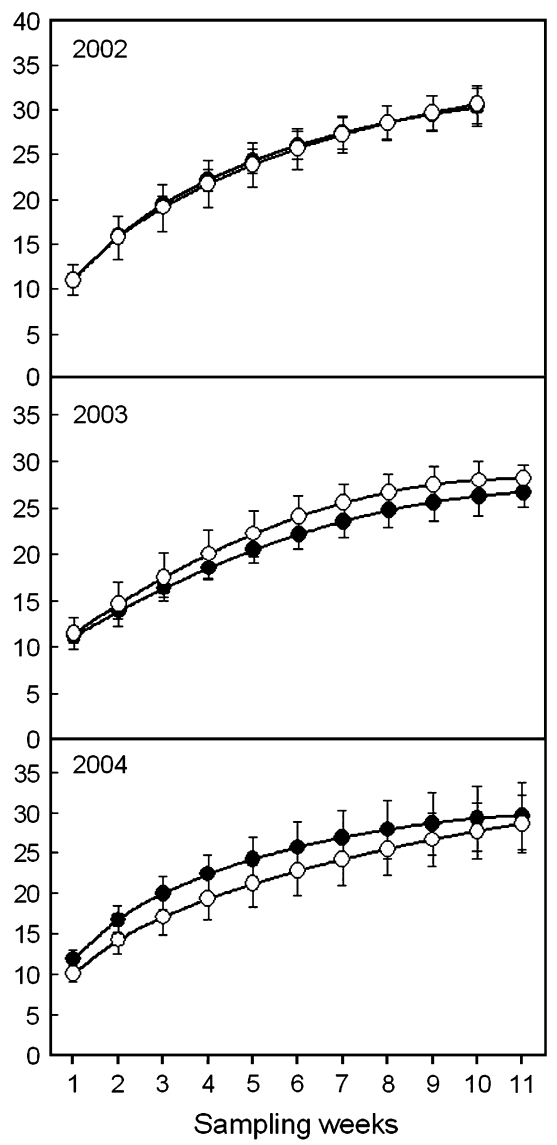

Figure 2 Comparison of species accumulation curves of ground-dwelling arthropods in Bacillus thuringiensis (Bt) and non-Bt cotton fields based on number of individuals collected and number of sampling weeks for each season from 2002 to 2004. 
H. gravis and Anisodactylus merula Germar - accounted for more than $80 \%$ of all carabids collected. Of the most abundant carabids, one is omnivorous (A. merula) and the other three are predominantly seed feeders (Larochelle \& Larivière, 2003). Among those species with a predatory habit, four species were more abundant, and the most abundant species again was the omnivorous A.merula. The others were Calosoma sayi Dejean, Harpalus pennsylvanicus DeGeer and Stenolophus ochropezus (Say) (Table 2). Among predatory heteropterans, there was relative constancy in numbers caught among the species, except for Nabis spp. and Geocoris uliginosus (Say), which were predominant in 2003 (85\%) and $2004(78.4 \%)$, respectively.

Diversity, dominance and species richness, as measured by the Shannon $\left(\mathrm{H}^{\prime}\right)$ and Simpson's indices, and total species richness are shown in Table 2 as means of the three fields within years for each cotton type. The 95\% confidence intervals of the estimated means comparing cotton types within year always overlapped. Both Shannon and Simpson indices tended to be lower in 2004 because of large collections of individuals representing few species, as indicated in the species accumulation curves (Fig. 2). Total species richness ranged from 36.9 to 39 species (Table 2), although the number of species per field within a season ranged from 25 species collected at Frazier field in 2004 to 35 at Marchant field in 2003, both in non-Bt cotton fields. Three new state records for Georgia were found: one spider, Falconia gracilis (Keyserling), a species accidentally introduced into the USA and already reported in Florida and Texas (Bonaldo, 2000), was collected in all 3 years, with abundance increasing from 2002 to 2004 and two carabid species, Apristus latens and Euryderus grossus Say, based on the catalogue of Bousquet \& Larochelle (1993) and Arnett (2000).

\section{Discussion}

The 3-year data show that Bt cotton fields sustain abundance and species richness of ground-dwelling arthropods of agronomic interest for cotton pest management at levels comparable to non-Bt cotton fields receiving reduced insecticide applications (Table 2 and Figs 1 and 2), despite changes in dynamics of potential prey targeted by $\mathrm{Bt}$ cotton. The mean differences for abundance of each species rated per pitfall trap (e.g. non-Bt mean minus Bt cotton mean) produced values of $0.0129,0.0204$ and -0.006 individuals per pitfall trap in 2002, 2003 and 2004, respectively. These values corresponded to an average of $1.29 \%, 2.03 \%$ and $-0.63 \%$ of difference between $\mathrm{Bt}$ and non-Bt fields, indicating no significant differences between cotton types.
The cotton field size (areas from 5.5 to 15 ha) and agricultural practices (insect control - Table 1) of the 18 fields studied from 2002 to 2004 reflect typical cotton production in the region. Assessment risks on commercial scales provide the most realistic field experiments for studying nontarget impacts of transgenic crops on natural enemies (Marvier, 2002; O'Callaghan et al., 2005). A concurrent study of the dynamics of foliage-dwelling predatory arthropods on Bt and non-Bt cotton, using the same fields, is reported in Torres \& Ruberson (2005). These pooled data reasonably cover most of the possible changes in ground- and foliage-dwelling arthropod communities of importance for pest management in the regional cotton ecosystem under standard grower farming practices.

Variation in total abundance among years was observed. The numbers of individuals collected per season increased from 2002 to 2004 (Table 2), although relative numbers averaged per trap were similar between cotton types and did not correlate with species richness (Table 2 and Fig. 2). This result was not unexpected because in 2002 , only 860 traps were recovered over 10 sampling weeks compared with 2003 and 2004, with 11 sampling weeks each. Also the number of individuals captured did not correlate with number of traps recovered in 2002 (Fig. 3), as few traps were lost in 2002 because of limited rainfall (144.5 mm accumulated over 25 rain days) compared with the following years. In 2003 and 2004, 1058 and 1153 traps were evaluated, respectively, and the number of individuals collected was positively correlated with number of traps evaluated (Fig. 3). Differences in total number of individuals between 2003 and 2004 can be explained by the additional 95 pitfall traps recovered in 2004. Rainfall also may have had some effect. In 2003, $470.4 \mathrm{~mm}$ of rainfall was accumulated over 43 rain days, whereas in 2004, only $245.0 \mathrm{~mm}$ of rainfall accumulated throughout 28 days of raining. Flooding and mud inside pitfall traps were the major causes of trap losses, resulting in the capture of relatively fewer individuals and a trend towards reduced means of individuals caught per trap in 2003 compared with 2004 (Table 2).

Although variation in the community structure was observed within and across years, there was no significant effect of cotton genotype (Fig. 1 and Table 2). The seedfeeding carabids S. palliatus and H. gravis, predominant species of our communities, were more abundant in 2003 than in 2002 and 2004, but this difference may have been as result of variation in weed availability. The extended rain frequency in 2003 delayed weed control at two of three locations in 2003 and, considering that these species feed on grass seeds (Larochelle $\delta$ Larivière, 2003), it is possible that weed seed was more abundant in 2003 as a result of limited herbicide use. Despite their 


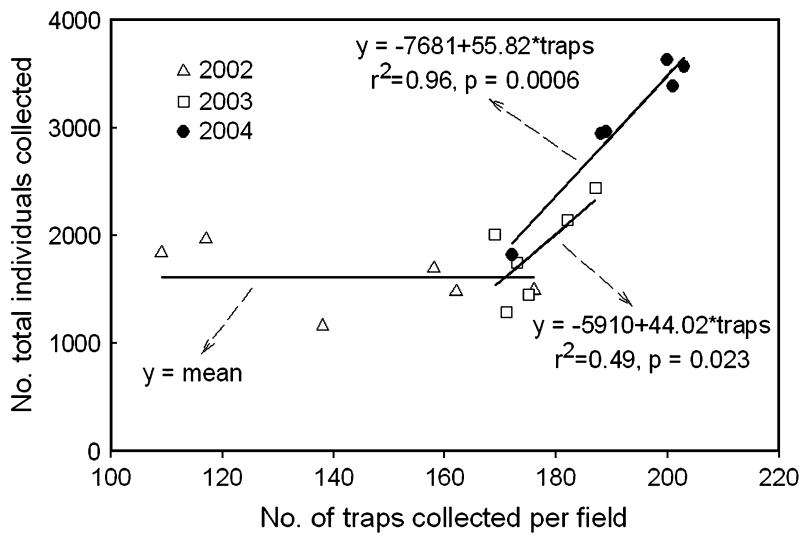

Figure 3 Effect of trap recovered per field on number of individuals collected (mean pooled per field of Bt and non-Bt cotton during 2002-04).

abundance in our fields, little is known about the life histories of S. palliatus and H. gravis, and they could be favoured by the high soil moisture resulting from extended rainfall in 2003 and the greater abundance of weeds that same year. In contrast, all dermapteran species were less abundant in 2003 compared with the other seasons, but this appears to have been because of the rotation of the third pair of fields (Table 1). The Ty Ty field and Frazier fields were major sources of $L$. riparia in 2002 and 2004, respectively, whereas the old House field used in 2003 had relatively low dermapteran abundance. Abundance of predatory heteropterans per pitfall trap decreased over the season, and less evident variation was observed for araneids and dermapterans. Predatory heteropterans sampled are predominantly plant foragers, except G. uliginosus, which is predominantly epigeal (Crocker \& Whitcomb, 1980). The decline in numbers of predatory heteropterans collected was consistent in Bt cotton fields but abundance was highly variable in non-Bt cotton fields (Fig. 1). This may be a response to the increased plant foliage area with seasonal progression, increasing the area for foliar foraging on both cottons and reducing activity on the ground, thereby lessening chance of capture by pitfall.

The greater variability of population dynamics in nonBt cotton fields corresponded with insecticide use on plant foliage (i.e. the first weeks of July and August) (Table 1). Therefore, the variability in population dynamics of ground-dwelling taxa, such as heteropterans, araneids and dermapterans, that forage in the plant canopy and ground is likely because of the impact of foliar insecticide. Strict epigeal species, such as most carabids, cicindelines and staphylinids, would likely not be as readily affected by foliar insecticides (Table 1). Disregarding the in-furrow treatment to control thrips, which was made on all fields at planting, insecticides were applied to control defoliating and sucking pests 22 times in non-Bt cotton versus 8 times in Bt cotton across all fields over 3 years (average of 2.4 applications per non-Bt field and 0.9 applications per Bt field; Table 1). The overall greater abundance of arthropods that might be expected in Bt fields as a result of lower insecticide pressure might have been masked somewhat in our study by use in non-Bt fields of a selective insecticide (spinosad; selective primarily for lepidopteran pests) that has short residual activity (Table 1). However, it is standard practice in the region to use selective insecticides as much as possible early in the season to conserve natural enemies. In addition, as mentioned above, most groups evaluated in this study forage predominantly on the ground; hence, foliar insecticides probably had limited impact. Given the reduced use of insecticides in Bt cotton and the greater use of selective insecticides in recent years, we would expect effective conservation of epigeal predators in cotton systems in the region.

The cicindeline M. carolina (Knisley \& Schultz, 1997), the carabid S. palliatus (Ciegler, 2000), the dermapteran L. riparia (Hoffman, 1987) and the araneid P. pauxilla (Breene et al., 1993) should be considered as significant species for monitoring of agroecosystem effects in the southeastern USA and for population comparisons representing important ground-dwelling taxa in modified cotton crop systems. All these species were frequently collected, are large and visually apparent, were consistently trapped in all locations and years and are taxonomically well defined.

The adoption of transgenic cotton has been considered detrimental for insect predators and parasitoids by directly eliminating prey/host availability or rendering prey/hosts unsuitable (reviews in $\mathrm{O}^{\prime}$ Callaghan et al., 2005). In this study, abundance and diversity of ground-dwelling arthropods (chiefly predators) in cotton fields were not affected during 3 successive years of growing transgenic Bt cotton using standard grower practices. The hypothesis elaborated for this study - that diversity and abundance of ground-dwelling predator arthropods would be reduced in Bt cotton - was not supported. Indeed, the use of transgenic cotton may generate positive changes in abundance and diversity of arthropods as a result of reduced applications of broad-spectrum insecticides in the Bt cotton ecosystem, making the system more salubrious for communities of ground-dwelling predators, although this difference was not observed in our lowinsecticide cotton production system.

\section{Acknowledgements}

We thank Miguel Michereff Filho (Embrapa-Recursos Genéticos/Brazil) and Steven Naranjo (United States 
Department of Agriculture-Agricultural Research Service, Western Cotton Research Laboratory, Phoenix, AZ) for valuable discussion on interpreting PRC analysis. Joe McHugh (University of Georgia, Athens, GA), Cecil Smith (University of Georgia Collection of Arthropods, Athens, GA), Michael C. Thomas and G.B. Edwards (Florida State Collection of Arthropods, Gainesville, FL) and Thomas Choate (University of Florida, Gainesville, FL) helped with species identification, and special thanks to grower Greg Davis for allowing us to use his fields and attending our requests and summer student workers for helping with field works. J. B. T. was granted by CAPES Foundation (BEX1315-005) from August 2001 to July 2005.

\section{References}

Arnett R.H. (2000) American Insects: A Handbook of the Insects of America North of Mexico. Boca Raton, Florida: CRC Press. Ball G.E., Bousquet Y. (2001) Carabidae Latreille, 1810. In American Beetles: Archostemata, Myxophaga, Adephaga, Polyphaga: Staphyliniformia, pp. 32-132. Eds R.A. Arnett and M.C. Thomas. Boca Raton, Florida: CRC Press.

Baumgarte S., Tebbe C.C. (2005) Field studies on the environmental fate of the Cryl Ab Bt-toxin produced by transgenic maize (MON810) and its effect on bacterial communities in the maize rhizosphere. Molecular Ecology, 14, 2539-2551.

Best R.L., Beegle C.C. (1977) Food preferences of five species of carabids commonly found in Iowa cornfields. Environmental Entomology, 6, 9-12.

Betz F.S., Hammond B.G., Fuchs R.L. (2000) Safety and advantages of Bacillus thuringiensis-protected plants to control insect pests. Regulatory Toxicology Pharmacology, 32, 156-173.

Bonaldo A.B. (2000) Taxonomia da subfamilia Corinninae (Araneae, Corinidae) nas regiões neotropical e neártica. Iheringia, 89, 3-148.

Bousquet Y., Larochelle A. (1993) Catalogue of the Geadephaga (Coleoptera: Trachypachidae, Rhysodidae, Carabidae including Cincidelini) of America North of Mexico. Memoirs of the Entomological Society of Canada, 167, 1-397.

Breene R.G., Dean D.A., Nyffeler M., Edwards G.B. (1993) Biology, Predation Ecology, and Significance of Spiders in Texas Cotton Ecosystems with a Key to the Species. College Station, Texas: The Texas Agricultural Experiment Station, B-1711.

Carmona D.M., Landis D.A. (1999) Influence of refuge habitats and cover crops on seasonal activity-density of ground beetles (Coleoptera: Carabidae) in field crops. Environmental Entomology, 28, 1145-1153.

Ciegler J.C. (2000) Ground Beetles and Wrinkled Bark Beetles of South Carolina (Coleoptera: Geadephaga: Carabidae and Rhysodidae). Clemson, South Carolina: Biota of South Carolina.
Cody R.P., Smith J.K. (1997) Applied Statistics and the SAS Programming Language. Upper Saddle River, New Jersey: Prentice Hall.

Colwell R.K. (2004) EstimateS: Statistical Estimation of Species Richness and Shared Species from Samples. Version 7. User's guide and application published at: http://purl.oclc.org/ estimates. Accessed March 2004.

Crocker R.L., Whitcomb W.H. (1980) Feeding niches of the big-eyed bugs Geocoris bullatus, G. punctipes, and G. uliginosus. Environmental Entomology, 9, 508-513.

Eyre M.D., Luff M.L., Rushton S.P., Topping C.J. (1989) Ground beetles and weevils (Carabidae and Curculionidae) as indicators of grassland management practices. Journal of Applied Entomology, 107, 508-517.

Frank S.D., Shrewsbury P.M. (2004) Consumption of black cutworms, Agrotis ipsilon (Lepidoptera: Noctuidae), and alternative prey by common golf course predators. Environmental Entomology, 33, 1681-1688.

Gotelli N.J., Colwell R.K. (2001) Quantifying biodiversity: procedures and pitfalls in the measurement and comparison of species richness. Ecology Letters, 4, 379-391.

Guillebeau P. (2004) Georgia Pest Management Handbook 2004. Athens, Georgia: The University of Georgia College of Agricultural and Environmental Sciences, Special Bulletin 28.

Harwood J.D., Wallin, W.G., Obrycki J.J. (2005) Uptake of Bt endotoxins by nontarget herbivores and higher order arthropod predators: molecular evidence from a transgenic corn agroecosystem. Molecular Ecology, 14, 2815-2823.

Head G., Surber J.B., Watson J.A., Martin J.W., Duan J.J. (2002) No detection of Cryl Ac protein in soil after multiple years of transgenic cotton (Bollgard) use. Environmental Entomology, 31, 30-36.

Hoffman K.M. (1987) Earwigs (Dermaptera) of South Carolina, with a key to the Eastern North American species and a checklist of the North American fauna. Proceedings of the Entomological Society of Washington, 89, 1-14.

Hopkins D.W., Gregorich E.G. (2003) Detection and decay of the $B t$ endotoxin in soil from a field trial with genetically modified maize. European Journal of Soil Science, 54, 793-800.

Hoy C.W., Feldman J., Gould F., Kennedy G.G., Reed G., Wyman J.A. (1998) Naturally occurring biological controls in genetically engineered crops. In Conservation Biological Control, pp. 185-205. Ed. P. Barbosa. San Diego, California: Academic Press.

Jo Y.K., Smitley D.R. (2003) Predation of Ataenius spretulus (Coleoptera: Scarabaeidae) eggs and grubs by species of Carabidae and Staphylinidae on golf courses in Michigan. Environmental Entomology, 32, 1370-1376.

Johnson N.E., Cameron R.S. (1969) Phytophagous ground beetles. Annals of the Entomological Society of America, 62, 909-914.

Kaston B.J. (1978) How to Know the Spiders. 3rd edn. Dubuque, Iowa: Wm. C. Brown Company Publishers. 
Knisley C.B., Schultz T.E. (1997) The Biology of Tiger Beetles and a Guide to the Species of the South Atlantic States.

Martinsville, Virginia: Virginia Museum of Natural History.

Larochelle A., Larivière M.C. (2003) A Natural History of the Ground Beetles (Coleoptera: Carabidae) of America North of Mexico. Sofia, Russia: Pensoft Publ.

Lattin J.D. (1989) Bionomics of the Nabidae. Annual Review of Entomology, 34, 383-400.

Lepš J., Šmilauer P. (2003) Multivariate Analysis of Ecological Data Using CANOCO. New York, NY: Cambridge University Press.

Lindroth C.H. (1961-1969) The Ground Beetles of Canada and Alaska, Parts 1-6. Lund, Sweden: Entomologiska Sällskapet.

Lövei G.L., Sunderland K.D. (1996) Ecology and behavior of ground beetles (Coleoptera: Carabidae). Annual Review of Entomology, 41, 231-256.

Marvier M. (2002) Improving risk assessment for nontarget safety of transgenic crops. Ecological Application, 12, 1119-1124.

NASS. (2004) National Agricultural Statistics Services, Agricultural Statistics Board. Washington, DC: The Department of Agriculture.

Nentwig W., Frank T.E., Lethmayer C. (1998) Sown weed strips: artificial ecological compensation areas as an important tool in conservation biological control. In Conservation Biological Control, pp. 133-153. Ed. P. Barbosa. San Diego, California: Academic Press.

O'Callaghan M., Glare T.R., Burgess E.P.J., Malone L.A. (2005) Effects of plants genetically modified for insect resistance on nontarget organisms. Annual Review of Entomology, 50, 271-292.

Reed G.L., Jensen A.S., Riebe J., Head G., Duan J.J. (2001) Transgenic Bt potato and conventional insecticides for Colorado potato beetle management: comparative efficacy and non-target impacts. Entomologia Experimentalis et Applicata, 100, 89-100.

SAS Institute. (1999-2001) SAS User's Guide: Statistics Version 8 for Windows. Cary, North Carolina: SAS Institute Inc.
Saxena D., Stotzky G. (2001) Bacillus thuringiensis (Bt) toxin released from root exudates and biomass of Bt corn has no apparent effect on earthworms, nematodes, protozoa, bacteria and fungi in soil. Soil Biology $\theta$ Biochemistry, 33, 1225-1230.

Saxena D., Flores S., Stotzky G. (1999) Insecticidal toxin in root exudates from Bt corn. Nature, 402, 480.

Sims S.R., Holden L.R. (1996) Insect bioassay for determining soil degradation of Bacillus thuringiensis subsp. kurstaki CryIA(b) protein in corn tissue. Environmental Entomology, 25, 659-664.

Sims S.R., Ream J.E. (1997) Soil inactivation of the Bacillus thuringiensis subsp. kurstaki CryIIA insecticidal protein within transgenic cotton tissue: laboratory microcosm and field studies. Journal of Agricultural and Food Chemistry, 45, 1502-1505.

Stinner B.R., House G.J. (1990) Arthropods and other invertebrates in conservation-tillage agriculture. Annual Review of Entomology, 35, 299-318.

Tooley J., Brust G.E. (2002) Weed seed predation by carabid beetles. In The Agroecology of Carabid Beetles, pp. 215-229. Ed. J.M. Holland. Andover, UK: Intercept.

Torres J.B., Ruberson J.R. (2005) Canopy- and grounddwelling predatory arthropods in Bt and non-Bt cotton fields: patterns and mechanisms. Environmental Entomology, 34, 1242-1256.

Van den Brink P.J., Ter Braak C.J.F. (1999) Principal response curves: analysis of time-dependent multivariate responses of biological community to stress. Environmental Toxicology and Chemistry, 18, 138-148.

Zwahlen C., Andow A.D. (2005) Field evidence for the exposure of ground beetles to Cryl Ab from transgenic corn. Environmental Biosafety Research, 4, 113-117.

Zwahlen C., Hilbeck A., Gurgerli P., Nentwig W. (2003) Degradation of the Cryl Ab protein within transgenic Bacillus thuringiensis corn tissue in the field. Molecular Ecology, 12, 765-775. 